\title{
Turkey and Cyprus: A Poliheuristic Analysis of Decisions during the Crises of 1964, 1967, and 1974
}

\author{
ÖzGür ÖZDAMAR \\ Bilkent University \\ AND \\ OKнаN ERcías \\ University of Leicester
}

\begin{abstract}
The Cyprus problem is one of the most protracted and complex conflicts in the world. This article uses poliheuristic (PH) theory to analyze Turkey's decision-making during the Cyprus crises of 1964, 1967, and 1974. We utilize the PH model (Mintz 1993, 2004) and its method to systematically examine the decision-making process and outcomes during the three crises. We present primary evidence from governmental archives and secondary from media sources. The two hypotheses derived from the PH literature are supported by evidence. Results confirm Turkish decision-makers employed two-stage decision-making during each crisis. In the first stage, Turkish leaders followed the noncompensatory rule and eliminated options that could incur losses. In the second stage, their calculations were more in line with expected utility maximization. Implications of the case study in terms of PH model, foreign policy analysis, and international relations theory are discussed in the conclusion.
\end{abstract}

\section{Introduction}

The Cyprus problem has been on top of the international agenda since the early 1950 s, involving great powers and the UN (United Nations) and bringing Turkey and Greece to the brink of war at least three times in three decades. The delicate situation in Cyprus makes it necessary to examine how the positions of the parties evolved over time, leading to Turkey's military intervention in Cyprus in 1974. The assumptions of poliheuristic $(\mathrm{PH})$ theory provide a clear explanation of why and how Turkey's decision differed in each of the three Cyprus crises.

\footnotetext{
We would like to thank Alex Mintz, Patrick James, Birol Yesilada, Nukhet Sandal, and Ahmet Sozen for their helpful comments on an earlier version of this article.

Özgür Özdamar is an associate professor of International Relations at Bilkent University and a visiting Fulbright scholar at SAIS, Johns Hopkins University. His research focuses on foreign policy analysis, leadership studies, forecasting and international relations theories. His articles have been published in journals such as the European Journal of International Relations, Political Research Quarterly, Terrorism and Political Violence, Foreign Policy Analysis, International Studies Review, Social Science Quarterly, Middle East Policy, and the Journal of Southeast European and Black Sea Studies. He currently serves as editor of All Azimuth: Journal of Foreign Policy and Peace and director of research at Center for Foreign Policy and Peace Studies. His latest coauthored book, Role Theory in the MENA: Politics, Economics and Identity, was published by Routledge in 2019. E-mail: ozgur@bilkent.edu.tr.

Okhan Erciyas is a PhD candidate at University of Leicester. His research focuses on foreign policy analysis, decisionmaking processes, and discourse analysis. E-mail: oe31@leicester.ac.uk.
} 
Cyprus is an island country in the eastern Mediterranean located to south of Turkey and southeast of Greece. Mostly populated by Greeks and Turks, the island was under Turkish rule for nearly three centuries until the United Kingdom took control in 1878. During the 1950s, British authorities faced stiff resistance from Greek Cypriots who demanded "enosis," unification of Cyprus with mainland Greece. British authorities rejected the demands. Turkish Cypriots lobbied for " $t a k$ sim," participation of Cyprus between Greek and Turkish communities. In 1960, after lengthy discussions, Cyprus gained independence under a treaty of guarantee between the United Kingdom (UK), Greece, and Turkey, based on the 1959 Zurich and London agreements. ${ }^{1}$

Administrative duties were divided between Greek and Turkish Cypriots in line with the island's demographic structure; such as there was a seven to three ratio in the House of Representatives of the Republic where the Greeks had the majority. Similar arrangements were in place in other civil and military duties (Adams 1966; Salem 1992). These governmental regulations caused tension between Greek and Turkish Cypriots and led to intercommunal strife as early as 1963. After a series of political crises in 1964, 1967, and $1974,{ }^{2}$ Turkey conducted a unilateral military intervention on July 20, 1974, citing its rights emanating from the Treaty of Guarantee (Bahcheli 2014). The effects of this decision are in place to this day: Cyprus is still a divided island and presents one of the most protracted conflicts in the world; Greek-Turkish relations have never fully recovered; and the issue stands as the biggest problem between Turkey and the EU.

This article analyses the Turkish leadership's decision-making during these three crises by using the PH decision-making model first introduced by Mintz (1993). The main questions we answer are as follows:

i. What were the major policy dimensions and options available to Turkey's leadership (i.e., the prime minister) in each crisis?

ii. How did the decision makers analyze these options; which options were eliminated and why?

iii. How did the decision makers reach a decision based on the remaining options?

iv. Why did Turkey, a middle power in world politics, refrain from a full-scale military operation in 1964 and 1967, yet decide to go for one in 1974?

The subsequent sections explain the literature on Turkey's decision-making on Cyprus policy, a discussion of PH theory, and an analysis of Turkish leaders' decisions during the three crises from the perspective of PH theory. The concluding section provides a discussion of the analysis's significance in terms of decision-making approaches, mainstream international relations (IR) theories, and Turkish foreign policy studies.

\section{Literature on Turkey's Decision-Making on Cyprus}

Although there are various studies on the Cyprus question in connection with Turkish foreign policy, there is little focus on the decision-making processes of Turkish leaders regarding those policies. ${ }^{3}$ Çuhadar-Gürkaynak and Özkeçeci-Taner (2004)

\footnotetext{
${ }^{1}$ There were three international treaties, signed in 1959 and 1960, that created the Republic of Cyprus: 1 . Treaty of Establishment; 2. Treaty of Guarantee; and 3. Treaty of Alliance. For readers less familiar with historical developments of Cyprus question in the twentieth century, Ker-Lindsay (2011) offers an easy to read account of the train of events.

${ }^{2}$ To identify the crises of this study, we used International Crisis Behavior Project (ICB) definitions (Brecher and Wilkenfield 2000; Brecher et al. 2017).

${ }^{3}$ There is a considerable literature on Turkey's policy toward Cyprus that this article also utilizes (Hale 2000; Oran 2001; Sönmezoğlu 1991, 1995, 2000; Uslu 2003; Bölükbaş1 2001; Constandinos 2011; Dodd 2010). However, this
} 
concentrated on the 1974 Cyprus crisis as a case of foreign policy decision-making in Turkey and suggest how Turkish decision-makers may have made their choices. Their work is an example of decision units' effects on the decision-making process. Sandal et al. (2011) compares Chinese and Turkish decision-making during international crises by using PH theory. They conclude that out of nine analyzed crises, Turkish leaders used two-stage decision-making in eight of them. Their analysis looks at the Turkish foreign policy crises in the second half of the twentieth century. More recently, Sirin (2012) studied how the contracting parties reached the 1959 Zurich and London agreements and decided to establish the Republic of Cyprus. Aside from these studies, the literature does not explore how Turkey's decisions around Cyprus were made. The current article will contribute to the literature by examining and comparing Turkish leaders' decision-making processes in the Cyprus crises of 1964, 1967, and 1974.

\section{Poliheuristic Decision Model and its Application}

There are two main schools of thought around political decision-making: rational choice and cognitive psychology (Mintz 2002, 1). The well-known assumption of the rational choice school is that "nations are led by rational, forward-looking, expected-utility-maximizing leaders" (Redd and Mintz 2013, 12). However, evidence suggests that decision makers do not always try to maximize benefits in reality. They regularly choose "irrational" options, leading some scholars to turn to alternative theories such as the bounded rational cybernetic approach (Below 2008, 3). However, these approaches may not be mutually exclusive: focusing only on the rational choice approach may only explain the decision maker's preferences, or concentrating solely on cognitive aspects of the issue may only explain processes and beliefs (DeRouen and Sprecher 2004, 56). PH theory, as an alternative to these schools, is a bridge between the rational and cognitive approaches (Mintz and DeRouen 2010, 78). The PH decision-making model explains both the "why" and "how" questions about a leader's decisions, arguing that policymakers adopt more than one decision strategy while making decisions (Mintz and DeRouen 2010, 78).

The model suggests that decision-making consists of two processes. In the first stage, leaders employ a "non-compensatory" decision-making strategy (Mintz and DeRouen 2010, 78), taking various dimensions of the issue into account, and eliminate policy alternative(s) that are unacceptable in a critical dimension. In the second stage of the decision-making process, leaders adopt a more rational approach and choose the best remaining option. According to the PH model, leaders consider the "political dimension" to be the above-noted critical dimension because each political actor's primary aim is remaining in power. Here, one may ask how this approach differs from Herbert Simon's (1957) bounded rationality model. While both theories have cognitive approaches, bounded rationality argues that decisionmaking is a search process where a leader continues searching for a "satisficing" policy alternative. Thus, the decision maker does not try to maximize benefits. PH model, however, argues that leaders want to maximize their benefits while avoiding "non-compensatory" decisions.

The model defines a key dimension(s) that must be satisfied to choose a policy alternative, and the alternatives are evaluated according to their total ratings (Brule 2005, 102). In this context, every leader, regardless of his or her nationality or ideology, makes noncompensatory choices to simplify the decision-making process (Brule 2005, 100). The noncompensatory decision process implies that there is no "substitution effect" between dimensions (Dacey and Carlson 2004, 40).

literature has taken the traditional diplomatic history approach and generally refrained from theorizing and engaging new methodologies. Especially agent-based decision-making theories have not been utilized save for the three exceptions mentioned above. 
For instance, during a foreign policy crisis, if the public strongly opposes the "doing nothing" option to deal with the crisis, the leader also most probably rejects passive options (because he or she wants to appeal to the public to remain in power), and he or she may consider proactive policy alternatives such as "apply sanctions" or "use force" (Mintz 2005, 97). Generally speaking, the noncompensatory choices will eliminate any decision that would endanger the leader's political survival.

Time pressure and complexity of the decision environment are other burdens on the decision maker, guiding the leader to use cognitive heuristics to eliminate unacceptable policy alternatives and to create simpler decision matrices (James and Zhang 2005, 35). Additionally, during international crises, policymakers might have multiple and conflicting goals, which is why, according to PH theory, decision-makers compare policy options in several (unevenly weighted) dimensions (Ye 2007, 319).

It is crucial to build a $\mathrm{PH}$ decision model before examining a decision. Mintz $(2005,95)$ states that building a PH model has two steps:

1. Identify the leader's decision matrix (e.g., the alternatives set, dimensions set, and implications of each alternative on each dimension).

2. Apply PH calculations to the decision matrix to explain or predict the ultimate choice.

While constructing the model, the researcher needs to define: (i) policy alternatives that the leader has, (ii) dimensions in evaluating the matrix, (iii) implications for each dimension, (iv) ratings for each option at each dimension, and (v) the total weight of each dimension (Mintz 2005). In the PH literature, four dimensions appear to be important in decision matrices: (i) political, (ii) economic, (iii) military, and (iv) diplomatic (James and Zhang 2005, 41). It is important to note that the decision matrix may consist of as many dimensions as the case requires.

Based on existing literature on Turkish foreign policy and the Cyprus crises (see Hale 2000; Sönmezoğlu 2000; Bölükbaş1 2001; Oran 2001; Uslu 2003; Dodd 2010; Constandinos 2011), this paper argues that during each crisis Turkish policy makers had four alternatives on the table: (i) military intervention, (ii) air strikes, (iii) diplomatic efforts, and (iv) doing nothing. Before discussing the dimensions, it is helpful to elaborate on these policy alternatives. First, "military intervention" referred to a full-scale military assault involving ground forces and resulting in the occupation of territory. "Air strike" indicates a limited military operation performed by air forces only. In the Cyprus context, an "air strike" decision aimed to cease intercommunity clashes on the island by attacking some strategic targets. The third policy option, "diplomatic efforts," refers to using peaceful methods to calm the situation. Such methods included engaging with guarantor states by organizing bilateral talks or conferences, or requesting mediation from a third party (e.g., the United States) or an organization (e.g., NATO, the UN). Last, a "do nothing" policy alternative referred to allowing Turkish and Greek Cypriots to settle the dispute among themselves without Turkey's involvement. In other words, by choosing the "do nothing" option, leaders would expect that the conflict would calm down as a result of negotiations between the Turkish and Greek Cypriot communities on the island.

This article argues that Turkish decision makers examined these policy options under three dimensions: (i) diplomatic, (ii) political, and (iii) military. Regarding the diplomatic dimension, the first Cyprus crisis erupted during the high-tension years of the Cold War, and there were other influential actors (i.e., the United States and the Union of Soviet Socialist Republics) involved. During the Cyprus 
crises, Turkey considered the reactions of these superpowers, as well as of other actors (e.g., the UK, the UN, and NATO). As Turkish decision makers prioritized maintaining Turkey's relations with its allies, Turkish leaders therefore assessed the possible reactions of third-party countries before making a decision regarding Cyprus.

The second dimension is political. As stated earlier, PH theory argues that domestic politics is the "essence of the decision." Leaders try to remain in power, and they consider policy alternatives with an eye to securing their office (Bueno de Masquita et al. 2003). During each decision on Cyprus, Turkey experienced unstable domestic politics, which made this dimension more important for Turkish leaders.

The last dimension is military. Turkey's capacity to intervene in Cyprus was a crucial aspect of this dimension. If Turkey had decided to send ground forces to Cyprus, it would have been the country's first unilateral use of force since its inception as a republic in 1923. Turkey's military capability and readiness were also among the questions Turkish decision makers had to consider in this dimension. Therefore, for each crisis, Turkish policy-makers' decision matrix appears to be as shown in Table 1 below.

In the diplomatic dimension, the alternatives are scored from highest to lowest according to their impact on Turkey's position in the international arena and the decision's effect on Turkey's foreign relations. Cold War and regional balance-ofpower concerns are of the highest priority here. In the political dimension, alternatives are ranked according to their ability to aid the leader's political survival and public opinion while improving the situation on the island for Turkish Cypriots and Turkey. In the military dimension, they are scored according to Turkey's ability to successfully achieve military objectives.

Based on this discussion and the PH literature (Mintz 1993, 2002; James and Zhang 2005; Sandal et al. 2011), we form our hypotheses about Turkey's decisionmaking in the three Cyprus crises as follows:

Loss avoiding phase: During each Cyprus crisis, Turkish leaders avoided political loss by using the noncompensatory rule.

Utility maximizing phase: During each Cyprus crisis, Turkish leaders wanted to maximize benefits and make the ultimate choice among the remaining options.

The case analyses are based on (i) the speeches and memoirs of Turkish decision makers on the Cyprus crisis during the 1960s and 1970s; (ii) session records

Table 1. Turkish politicians' decision matrix ${ }^{1}$

\begin{tabular}{|c|c|c|c|c|}
\hline \multirow[b]{2}{*}{ Policy Options } & \multicolumn{3}{|c|}{ Dimensions } & \multirow[b]{2}{*}{ Total (Average) } \\
\hline & Diplomatic (1-4) & Political (1-4) & Military (1-2) & \\
\hline \multicolumn{5}{|c|}{ Military intervention } \\
\hline \multicolumn{5}{|c|}{ Air strike } \\
\hline \multicolumn{5}{|c|}{ Diplomatic efforts } \\
\hline Do nothing & & & & \\
\hline
\end{tabular}

${ }^{1}$ Each dimension has a value range depending on how many viable options the leader had at that time. Under each dimension the options are ranked by their expected utility units. Accordingly, under the "diplomatic dimension," every policy option has implications on the outcome, hence each of them is weighted from 1 to 4 . The same range is also applicable for the "political dimension," where alternatives have possible impacts on the leaders' political survival. Under the "military dimension," only the "military intervention" and "air strike" options are relevant. Thus, the weighting under the last dimension ranges from 1 to 2 , only. 
of the Grand National Assembly of Turkey (TBMM); (iii) related media coverage in a major daily newspaper, Milliyet; and (iv) selected books, chapters, and articles on the Cyprus crises. We use both primary and secondary sources to recreate the decision-making processes of Turkish leadership. More specifically, using the Turkish parliamentary minutes to trace the decision-making process is one of the original contributions of this article. To check the validity of our findings, we asked a third coder to evaluate the events in chronological order and use the same scale for evaluation.

\section{The 1964 Crisis}

When political problems were exacerbated regarding governing Cyprus, the Greek Cypriot side proposed changes to the constitution. Although there was preexisting tension between Turks and Greeks on almost every issue, in late December 1963 an incident triggered violent intercommunity conflicts, and there were casualties on both sides (Oran 2001; Mallinson 2005). At the time of the crisis, Turkey was ruled by a coalition led by CHP (Republican People's Party) and supported by independent members of parliament (MPs). CHP leader İsmet İnönü was the prime minister $(\mathrm{PM})$.

During the early stages of the 1964 Cyprus crisis, Turkey responded with only a show of force. Turkish military jets flew over the island. Although this reaction resulted in ceasing ethnic conflict on the island temporarily, the situation reescalated in the following months, until June 1964. As a result, Turkey announced its intention to intervene in Cyprus militarily to restore order and the status quo established by the treaties. At this stage, the US administration took the initiative to prevent Turkey from intervention. The Turkish government decided to go for a limited "air strike" option. The current article focuses on Turkey's decision-making process during the 1964 crisis, from the eruption of intercommunal conflict in December 1963 to Turkey's limited air operation in August 1964.

\section{The First Stage of Decision-Making}

From the beginning of the Cyprus crisis, Turkish PM Inönü insisted on solving the question within the framework of the 1959 treaties that laid the foundation of the Republic of Cyprus. Inönü's commitment to the international agreements was related to his attitudes toward foreign policy. In general, he was in favor of cautiousness on foreign policy. According to İnönü (1961, 45), solving disputes through negotiation requires two conditions from the parties involved: (i) an agreement on the existence of the conflict and (ii) the decision to resolve the problem. These views demonstrate that İnönü favored an approach of prioritizing negotiation over force as a means of solving disputes.

When the 1964 crisis emerged, and authorities could not stop the violence among Turks and Greeks, Turkey considered military intervention in Cyprus. Nonetheless, intervention remained a last resort on İnönü's agenda, and he decided to exhaust other alternatives (Bölükbaşı 1993, 512). According to Toker (1992, 195-96), Inönü was reluctant to use force; he described it as "putting a stick in a hive." ${ }^{4}$ Further, at that time Turkey was trying to get US support for its claims regarding the protection of the Turkish community.

Inönü argued that safeguarding security and public order on Cyprus required the commitment of the superpowers. He declared that only after this commitment would it be possible to find a solution (MMTD 1964, 12). In other words, Inönü considered internationalization of the dispute as a step toward the settlement. Yet in

\footnotetext{
${ }^{4}$ An expression in Turkish similar to "poking the bear" or "opening the can of worms" in English.
} 
February 1964, during the London conference that convened to find a resolution to the problem, Britain tried to include the United States in efforts to solve the dispute. This attempt, however, paved the way for the USSR's involvement in the Cyprus question due to Cold War dynamics (Aziz 1969, 173). While creating a peacekeeping force under the umbrella of NATO was considered, the idea was dismissed by the Greek Cypriot authorities and lacked support from other NATO members. The solution was found under the auspices of the United Nations (Ker-Lindsay 2004). However, even after the formation of the UN peace-keeping force on Cyprus in March 1964, the conflict persisted and became even more complicated (Sambanis 1999).

At this point, the Turkish government considered using the Turkish Cypriot paramilitary organization Turkish Resistance Organization (Türk Mukavemet Teskilatı, TMT) to protect the Turkish minority. However, TMT's capabilities were limited to local resistance. The İnönü government did not consider TMT capable enough to protect Turkish interests on the island (Keser 2007). During those difficult days, the TBMM granted the Inönü administration the authority to intervene in Cyprus when required.

In the spring of 1964, Inönü claimed that if the intercommunity strife did not end soon, the Western Alliance would dissolve (Kışlalı 1964), indicating that he would use force in Cyprus that could lead to a Turkey-Greece war and dissolution of NATO. We argue that Inönü was bluffing, and if he were seriously considering military intervention, he certainly would not have regularly discussed the Cyprus dispute with other NATO members, especially the United States. Bölükbaşı $(2001,123)$ also argues that Inönü's demands for consultation from the United States were a sign of his unwillingness to intervene. A memorandum sent from US Undersecretary of State George Ball to President Johnson states:

\footnotetext{
Inonu is doing everything possible to manoeuvre us into taking responsibility for bringing about a settlement. . . They also want us to force a settlement on themprovided adequate face-saving aspects can be devised. (FRUS 2000, 132)
}

In sum, the Turkish PM pursued a ternary strategy, which involved including the United States in the negotiations, using the unity of the NATO alliance as a bargaining chip to get attention of the United States and European powers, and emphasizing the threat of the USSR in the region. Nihat Erim, who served as an MP from CHP at the time, gives a first-hand account of Turkey's policy toward Cyprus. Erim suggests that Inönü did not want to put Turkey in danger while trying to protect a mere 120,000 Turkish Cypriots (Erim 1975, 383). In other words, Turkey could not act without considering the consequences of a decision to intervene.

We argue that IR, represented as the Cold War's systemic constraints, was the most important factor in Inönü's decisions during the 1963-1964 Cyprus crisis. Using $\mathrm{PH}$ theory, we argue that, despite public announcements showing the intention to conduct a large-scale military intervention, İnönü actually eliminated the "military intervention" option in the first stage of decision-making because this option failed to satisfy his key dimension (i.e., the diplomatic dimension). İnönü was aware of the dangers of such military involvement during the peak of Cold War tensions. The PM upheld the 1959 agreements as a result of international and intra-alliance pressure (especially US opposition to military intervention) and thus decided not to conduct a full-scale military intervention in Cyprus.

\section{The Second Stage of Decision-Making}

Eliminating the "military intervention" alternative in the first stage left Inönü with three policy options: (i) air strike, (ii) diplomatic efforts, and (iii) doing nothing. 
This article evaluates each policy alternative according to the remaining dimensions: political and military.

Politically, Inönü perceived himself as a cautious and responsible statesman in his role as the leader of Turkey and tried to rebuff nationalist backlash in the parliament. When the situation in Cyprus rang alarm bells, İhsan Sabri Çağlayangil, a senator from the opposition AP (Justice Party), accused Inönü of not following through on the decision to intervene in Cyprus (CSTD 1964, 188-89). In reply, Inönü stated that Turkey did not have the right to intervene whenever it wished to do so (CSTD 1964, 197). The American embassy in Ankara soon realized that the Inönü administration was under severe criticism as a result of its Cyprus policy. The US ambassador, Raymond A. Hare, acknowledged that the US government appreciated the Turkish government's restraint (FRUS 2000, 20).

Despite US support for the İnönü administration's decisions, the domestic opposition became evident when Inönü asked for a vote of confidence before his visit to Washington in June 1964. The İnönü coalition witnessed perhaps its most difficult days prior to the vote and was only narrowly successful (Milliyet 1964). In terms of the military dimension, the critical question was if Turkey decided to intervene in Cyprus, did it have the capability to carry out the military operation? The formation of the National Guard by Greek Cypriots and the presence of Greek resistance provided an additional constraint for Turkey to consider (O’Malley and Craig 2001). While the task was challenging, at least the United States was under the impression that Turkey was on the eve of sending troops to Cyprus.

\section{The 1964 Decision}

In the second stage, the Inönü administration evaluated the remaining policy alternatives according to their total ratings, and the most favorable decision appeared to be to conduct an "air strike."

In the diplomatic dimension, the most desirable option was "diplomatic efforts," as this option would not cause a regional war and a crack in the existing NATO alliance and would ease the pressure from third parties (i.e., the United States and/or the USSR). The events showed that Turkey received serious criticism from the superpowers when it announced its intention to intervene. It is important to note that the early 1960s witnessed the high tension of the Cold War, and being a member of the Western Bloc put Turkey in the forefront. One of the most visible examples of this dynamic was the Cuban missile crisis of 1962, which was still fresh in political memory (Hale 2000). Turkey, of course, was negatively affected by these tensions and had to be cautious in making foreign policy decisions, especially to use force.

To recap, in the political dimension (which, as mentioned above, refers only to the domestic political situation), the "military intervention" option ranked as the best choice. The public and opposition parties were expecting some action toward Cyprus to provide security for Turkish Cypriots. Thus, the administration had to choose a policy option that would look like the government was paying enough attention, without threatening its survival at the same time. In the military dimension, the "air strike" option scored as the best policy alternative. Turkey's capacity to carry out a full-scale military operation was relatively lower than its ability to engage in air strikes (Oran 2001).

Inönü, one of the founding fathers of the Turkish Republic, considered himself responsible for its future survival (Heper 1998). Despite domestic opposition, he pursued a foreign policy based on diplomacy and negotiation, as he felt that would lead to the best outcome for Turkey overall. After realizing that the situation was changing against Turkey's regional interests, the İnönü administration declared its intention to intervene in Cyprus. The plan was stopped by President Johnson's 
Table 2. PM İnönü's decision matrix during the 1964 crisis

\begin{tabular}{lcccc}
\hline & \multicolumn{3}{c}{ Dimensions } \\
\cline { 2 - 4 } Policy options & Diplomatic & Political & Military & Total (Average) \\
\hline Military intervention & 1 & 4 & 1 & $6(2)$ \\
Air strike & 2 & 3 & 2 & $7(2,3)$ \\
Diplomatic efforts & 4 & 2 & - & $6(2)$ \\
Do nothing & 3 & 1 & - & $4(1,3)$ \\
\hline
\end{tabular}

well-known letter, which was designed to dissuade Turkey from a broad military operation. We argue that Johnson's letter actually helped Inönü, as it provided a face-saving justification not to use force (FRUS 2000; Şahin 2002) and eliminated any possibility of Soviet retaliation on Turkey. Table 2 summarizes İnönü's decision matrix.

İnönü eliminated the full-scale military intervention as a noncompensatory option because of the immense foreign policy problems it would create for Turkey. In the second stage, we argue, Inönü engaged in more analytical expected-utility-like decision-making. In this stage, "do nothing" was not a feasible option because it would cause a stronger domestic opposition to the government in the parliament. Therefore, the PM used a balanced approach using diplomacy accompanied by the intention to use force. When all diplomatic efforts failed to stop the intercommunal conflict, İnönü ordered limited air strikes, which seemed to be the preferred choice at the time. Air strikes on August 8-9, 1964, eventually stopped the violence on the island and led the parties to return to the negotiation table.

\section{The 1967 Crisis}

Following the 1964 crisis, Cyprus entered in a period of peace, though the parties were far from a lasting solution. From time to time, the Cyprus question emerged as an international issue, but the Turkish public gradually lost interest in it. The Cyprus dispute entered a new phase when a coup took place in Greece in April 1967. The "Greek Junta" that ruled the country until 1974 sought to achieve enosis as quickly as possible (Miller 2009). The Greek government attempted to convince Turkey to accept enosis during bilateral discussions. Turkey did not accept these offers (Hart 1990). In late 1967, Turkey and Greece were again on the brink of war, due to events taking place in Cyprus. During that crisis Turkey several times announced its intention to intervene but did not make the final war decision. Instead, it pursued only "diplomatic efforts." This article next explores Turkey's decision-making process during the 1967 Cyprus crisis, from the Turkish election of 1965 to the eruption of the crisis in November 1967.

\section{The First Stage of Decision-Making}

The İnönü coalitions (1961-1965) were fragile. The opposition, center-right AP (Justice Party) won Turkey's 1965 general elections, and Süleyman Demirel was appointed as prime minister. The AP considered itself a party of "social justice" and felt that the way to achieve this justice was "through a real increase in the national income" (Levi 1991, 140). In other words, the AP prioritized economic growth.

In November 15, 1967, the Greek Cypriot National Guard, under the command of General Georgios Grivas, attacked Turkish villages resulting in death of Turkish Cypriots. Turkey immediately protested. Greece called General Grivas back to Athens, and he resigned from commanding Greek forces on Cyprus. However, 
Greek troops remained in the island. Turkish decision-makers continued to protest Greece's presence in the island, and the United States increased pressure on Greece to find a solution to the problem (Sönmezoğlu 1995, 25-26; Coufoudakis 2003).

In this stage, the "political dimension" was considered the key dimension by the Demirel administration. Before the 1965 election, the AP published a manifesto arguing that Turkey should pursue a foreign policy away from "adventures" (AP 1965, 31 ) and consolidate its energy to developing the country. On the Cyprus issue, the document stated that the AP "sincerely" (AP 1965, 32) wanted to solve the dispute through negotiations with Greece on the basis of existing agreements, while defending Turkey and Turkish Cypriots' interests. The manifesto went on to say that the AP's approach should not be considered a "weakness" (AP 1965, 32) since the party would retaliate against any act contrary to Turkey's interests. While fostering development at the expense of losing Cyprus was not an option for the Demirel administration, the domestic political atmosphere was not conducive to perceived passivity. As a result, the government decided to eliminate the "do nothing" policy alternative during the first phase of its decision-making process regarding Cyprus.

\section{The Second Stage of Decision-Making}

Demirel had three remaining policy options: (i) military intervention, (ii) diplomatic efforts, and (iii) air strikes. We explore each policy alternative.

The rapprochement process between Turkey and the Soviet Union had begun during the third İnönü coalition, and the process gained momentum during PM Demirel's administration. The Demirel government not only established cordial relations with the Soviet Union but also cooperated with the Soviets on economic matters. For instance, the Soviets extended credit and technical assistance for constructing some noticeable industrial projects in Turkey. Although Turkey did not shift its foreign policy orientation from the West, the administration established relations with the Soviets and with Arab countries to pursue Turkey's economic development (Komşuoğlu 2008, 165; AP 1972). It is important to note that although the basis of Turkey's new foreign policy was economic, dialogue about Turkey's other policies naturally took place. As a result, the attitude of the Soviet Union became relatively more "supportive" for Turkey on the Cyprus dispute. As Mehmet Ali Aybar, the leader of the socialist TIP (Workers Party of Turkey), discussed in parliament, the Soviets, though still against foreign military presence on the island, adopted a policy supporting a bicommunal solution in Cyprus (MMTD 1965). Due to these improving relations, there was almost no reference to the Soviet Union as a threat during the 1967 Cyprus crisis (Göktepe 2005).

With the escalating tension between Turkey and Greece over Cyprus, the US government appointed Cyrus Vance-a former deputy secretary of defense-as a mediator, and he immediately began a "shuttle diplomacy." During his mission, Vance received heavy criticism from the Turkish public. Demonstrators argued that although the United States had prevented Turkey from using American arms on Cyprus in 1964, Greece was now using such weapons against Turkish Cypriots (Uslu 2003). Then-president Cevdet Sunay declared Turkey's intention to end the dispute "once and for all" (Purcell 1969, 383).

Parker Hart, then-US ambassador to Turkey, delivered a message to Foreign Minister İhsan Sabri Çağlayangil, explicitly expressing that he did not bring a letter that could be subject to a conversation, like the Johnson letter. When the ambassador declared that the "prospect of a war between two allies was a nightmare for us all," Çağlayangil replied that going "through this nightmare once and for all is preferable to seeing a nightmare every night" (FRUS 2000, 648-50).

Demirel had criticized İnönü for not discussing use of force as an option when the latter was in power. Yet, as PM, Demirel also pursued a cautious foreign policy 
(Hale 2000, 153), refraining from the use of force during the crisis. Turkey had warned Greece that it would retaliate if the situation on the island did not change and Greek troops did not cease fire and retreat. The message reached its intended audience when the US administration got involved and tried to prevent a war between its NATO allies. However, Turkey's capability to intervene "successfully" in Cyprus was again a question. Arcayürek (1985, 118-19) argues that although Turkey wanted to intervene, its capacity was limited. Turkish generals argued that the amphibious landing would be complicated, requiring a significant number of landing craft, helicopters, and air-landing brigades. Although there had been an effort to build up Turkey's military industry, in the 1960s, the country was not manufacturing landing craft (Yavuzalp 1996, 115-16).

\section{The 1967 Decision}

In the second stage, the Demirel administration evaluated the remaining policy alternatives according to the consequences of each action, and the most favorable decision became "diplomatic efforts." Placing the information on the crisis in the decision matrix, we see:

In the diplomatic dimension, the most desirable option was "diplomatic efforts." Solving the question by peaceful methods would be ranked higher than the other alternatives since this option would not cause a war in the region. It is noteworthy that although there was a rapprochement between Turkey and the USSR, the Soviets were still not supportive of a military operation against Cyprus.

In the political dimension, the "military intervention" option ranked as the best choice. When in opposition, the AP had strongly criticized the Inönü administration during the 1964 crisis, which is why the new AP government felt that exercising restraint would cause it to lose face. However, since Demirel's priority was economic development, a war could severely damage Turkey's development plans, and thus the AP tried to find a nonmilitary solution to the crisis. Under the military dimension, the "air strike" option scored as the best policy alternative since Turkey's capacity to carry out a full-scale military operation was again limited.

Overall, the diplomatic and political dimensions were the most important for the Demirel government's aims; thus, pursuing a policy based on diplomacy was the priority. However, since both public opinion and parliament were demanding a strong response to the Cyprus issue, the government had to find an optimal policy. Thus, the administration tried to force Greece to withdraw its troops that exceeded the limits granted under the existing agreements. It appears likely that with this move, the administration had two objectives: (i) calming the anger of the public and the nationalist backlash and (ii) preventing Greek troops from attacking Turkish Cypriots. The move was partially successful, since Greece called General Grivas back to Athens, and attacks on Turkish villages stopped. Table 3 summarizes Demirel's decision matrix.

During the 1967 Cyprus crisis, Turkey achieved almost all of its objectives with the help of its diplomatic efforts and US mediation: Additional Greek forces retreated

Table 3. PM Demirel's decision matrix during the 1967 crisis

\begin{tabular}{lcccc}
\hline & \multicolumn{3}{c}{ Dimensions } \\
\cline { 2 - 4 } Policy options & Diplomatic & Political & Military & Total (Average) \\
\hline Military intervention & 1 & 4 & 1 & $6(2)$ \\
Air strike & 2 & 2 & 2 & $6(2)$ \\
Diplomatic efforts & 4 & 3 & - & $7(2,3)$ \\
Do nothing & 3 & 1 & - & $4(1,3)$ \\
\hline
\end{tabular}


from Cyprus and Turkish Cypriots who suffered during that time would receive compensation. Furthermore, General Grivas, one of the leading supporters of enosis, had left Cyprus. However, as was the case with the 1964 crisis, the end of the 1967 crisis did not lead to a permanent solution to the dispute.

\section{The 1974 Crisis}

With a shaky peace restored on the island, the Demirel administration again focused on domestic politics after 1967. However, during the following years, Turkey witnessed widespread demonstrations, protests, and internal unrest. In 1971, the army intervened for the second time in modern Turkish history, and the Demirel administration stepped down from the government. Until 1974, Turkey was ruled by nonpartisan governments. A new coalition government was formed by the new CHP leader Bülent Ecevit and MSP (National Salvation Party, Islamist-right) leader Necmettin Erbakan in 1974 (Arcayürek 2006).

The CHP-MSP coalition adopted foreign policy decisions that damaged the alliance between Turkey and the West in general and with the United States in particular. Turkey's relations with Greece were also problematic due to a conflict regarding the Aegean Sea. In June 1974, Cypriot President Makarios sent a letter to the Greek junta and demanded the retreat of Greek officers from the National Guard in Cyprus on the basis that they were disregarding his authority. Makarios maintained that the EOKA-B-the successor of the pro-enosis paramilitary organization that fought against the British rule and Turkish community-was against his rule and that their activities were funded by the Greek junta (Danopoulos 1982; Gürün 1983).

On June 15, 1974, a successful coup took place in Cyprus against President Makarios' administration, organized by the EOKA-B and the Greek junta in Athens. Although British and American intelligence foresaw a possible coup to topple Makarios, both governments expected that as a distant possibility. As the coup took place, the United States and UK feared a Greco-Turkish war (Asmussen 2008). Turkey perceived this move as a clear step toward unification of Cyprus and Greece that was considered to be a "red line" not to be crossed. Turkey declared its intention to intervene immediately, and a full-scale military operation began on July 20, 1974.

\section{The First Stage of Decision-Making}

The Ecevit administration considered the "diplomatic" dimension to be the key dimension and eliminated any option that failed to satisfy the administration's expectations. After weighing the options available to the government, we argue that the Ecevit administration eliminated "do nothing" as a policy alternative. In the first place, Turkish Cypriots were under a more serious threat than at any time since the 1964 crisis. Establishing enosis at any cost was one of the main objectives of the coup plotters, who could consider attacking the Turkish population to pacify their resistance against unification of Cyprus with Greece (Kaufmann 2007). In the second place, abstaining from action would result in the acceptance of de facto enosis and old-time rival Greece's expansion south of Turkey. The Ecevit administration considered Greek expansion in Aegean Sea a threat to Turkey's security and warned Greece not to cross Turkey's red lines (Birand 1987; FRUS 2007; Rizas 2009). The coup, therefore, created an emergency situation that required "action," according to the government. In this phase, the administration also rejected the "air strike" policy option, as this alternative would not be sufficient to restore the state of affairs on the island, for this time the problem was much more serious, and a de facto unification with Greece had already been achieved by the coup. An air strike could, temporarily, prevent clashes between two communities but would not force coup plotters to retreat from the island and restore peace (Hughes-Wilson 2011). 
As an indication of the government's understanding at that time, in the parliament, Ecevit stated that "Greece did not leave breathing room for Turkey in the Aegean Sea, and it definitely would do the same in the Mediterranean Sea. As a result, a definite solution had to be found for this situation" (MMTD 1974, 21). Ecevit's words imply that the coup in Cyprus and de facto enosis triggered Turkey's reaction. The National Guard of Cyprus had established a new rule under Nikos Sampson, and Turkey realized that the status quo on the island had collapsed. When President Makarios fled from Cyprus, he declared that the Turkish community was in danger on the island, and the coup was a direct attack on the independence of the Republic of Cyprus (Ertekün 1984, 32). The Ecevit administration was faced with a situation that would require radical action to reestablish constitutional order on the island.

\section{The Second Stage of Decision-Making}

PM Ecevit eliminated the "do nothing" and "air strike" options in the first stage and had two remaining policy choices: (i) military intervention and (ii) diplomatic efforts. We begin by discussing diplomatic efforts and an evaluation of the Ecevit administration's foreign policy at the time.

Following the 1971 military intervention, nonpartisan governments ruled Turkey. The first such administration, headed by a former CHP MP Nihat Erim, imposed a ban on opium cultivation. The ban was demanded by US President Nixon's administration, which aimed to prevent the production of illegal drugs from opium grown in Turkey (Erhan 1996). One of the early decisions of the Ecevit administration was to revoke the ban on opium cultivation. Although the motivation was mainly to impress domestic audiences, the issue turned out to be an international problem between the United States and Turkey. Deteriorating relations with the United States did not come as a surprise to the Turkish administration, for it aimed to pursue a "determined" and "independent" foreign policy (Bölükbaşı 2001; Ecevit 2010, 216). The Ecevit administration was also dealing with the Aegean Sea demarcation dispute. Ecevit (2010) stated that he decided to negotiate with Greece although he did not have much hope of achieving an agreement. When negotiations ended without any concrete progress, Ecevit noted that he confronted criticism from opposition parties (Ecevit 2010). In sum, Ecevit's coalition government had already experienced a "rough start" in terms of foreign affairs in the first year leading up to the 1974 crisis.

In this context, the Ecevit administration considered the "diplomatic dimension" to be the key dimension during the crisis. After the coup, Ecevit went to London to discuss the matter with the other guarantor power, the UK. Ecevit wanted to discuss the "intervention" option to reestablish the state of affairs of the Cyprus Republic. During his visit, Ecevit emphasized the need for urgent action. In 1976, Ecevit (2010, 76) stated that although he did not have high expectations for cooperation from the British, he had to first attempt to negotiate the issue. Ecevit argued that by this move he wanted to secure Turkey's rights originating from the guarantee agreement of 1960. The US administration also wanted to take part in negotiations, which Turkey vetoed on the grounds that the United States was not a guarantor state. Instead, Turkey and the United States had separate talks (Oran 2001; Dodd 2010). The US secretary of state, Henry Kissinger, appointed a US diplomat, Joseph Sisco, to mediate between parties. Sisco offered "normalization" of US aid and warned Turkey of possible Greek retaliation. The United States, for the third time, was trying to prevent a war among NATO allies (Kissinger 1982).

In London, Ecevit's perception was that the British authorities were neither trying to prevent Turkey from intervening nor giving permission for it. Ecevit described the situation in the Turkish parliament: "In London . . . I got this impression: Of course, they [British and Americans] did not give us the green light to intervene 
in Cyprus, but there wasn't a red light either" (MMTD 1974, 24). In addition, the 1974 crisis took place in the midst of the détente period that witnessed an easing of tensions and thaw between states from two poles such as Turkey and the USSR. Systemically, the 1974 crisis included less bipolar tensions and constraints on Turkey.

Concerning the political dimension, Turkish opposition parties expressed their support for the government when the latter decided to intervene in Cyprus, although they were critical of the Ecevit administration's foreign policy in general. Before the coup, Demirel, leader of opposition AP, accused the government of trying to veil economic problems with international crises, in particular the Aegean dispute. Despite Ecevit's belief that the coalition would remain in office for a long time, the government was far from stable. Ecevit even considered resignation from the premiership in May 1974 (Milliyet 1974) and finally did so in September of that year, after the Cyprus crisis was over.

Another important difference between the previous two crises and 1974 was the Turkish armed forces' capacity to conduct a full-scale military operation in Cyprus (Evcil 1999). When the renewed Cyprus crisis erupted in the summer of 1974, Turkey was now technically prepared to intervene. In 1967, Turkey had only six helicopters, two landing crafts, and 150 parachutes; in 1974, it had a hundred helicopters, a hundred landing crafts, and fifteen thousand parachutes (Bölükbaşı 2001, 235).

\section{The 1974 Decision}

In the second stage, the Ecevit administration evaluated the remaining policy alternatives according to their expected consequences. Using the decision matrix, we show that the most favorable decision overall became "military intervention".

Under the diplomatic dimension, "diplomatic efforts" emerged as the most favorable option. Solving the question by peaceful methods ranked higher than other alternatives since, as with the previous crises, this option would not cause a war between Greece and Turkey. Thus, this option would ease the pressure from third parties, especially the United States. However, the 1970s witnessed a lower level of tension between the Eastern and Western Bloc in terms of Cold War dynamics, which figured into Turkish decision makers' ultimate choice; US public attention was furthermore on the Watergate scandal, not on Cyprus. ${ }^{5}$

Under the political dimension the "military intervention" option, again as with the previous crises, ranked as the best choice because the Turkish public and opposition parties had been expecting some action for years. Additionally, when the coup took place in Cyprus, the CHP-MSP coalition was already experiencing difficulties. Politically, not focusing on the Cyprus problem would have proven very unpopular for Ecevit's CHP.

Under the military dimension, the "military intervention" option scored as the best policy alternative. Turkey's primary aim was restoring the status quo of the Cyprus Republic, and the other military option (i.e., "air strike") would not force Greek authorities to step down from the government on Cyprus. During the previous Cyprus crises, Turkey's military readiness was a big question for Turkish decision-makers. In 1974, however, after nearly ten years of preparation, Turkey had the military capacity and strategy to intervene in the island. Table 4 summarizes Ecevit's decision matrix.

From the Turkish leadership's perspective, allowing the unification of Cyprus and Greece would significantly tip the regional balance of power toward Greece. The

\footnotetext{
${ }^{5}$ Contrary to Constandinos (2009), the United States wanted to put pressure on Turkey to discourage it from using military force. The United States' failure to prevent Turkey from full scale military operation, however, was due to Turkey's rapid action in 1974. While Hitchens (1997) indicated US support for the Greek junta's Cyprus policies, both Constandinos (2009) and Asmussen (2008) provide the opposite view based on recently declassified archival documents.
} 
Table 4. PM Ecevit's decision matrix during the 1974 crisis

\begin{tabular}{lcccc}
\hline & \multicolumn{3}{c}{ Dimensions } & \\
\cline { 2 - 4 } Policy options & Diplomatic & Political & Military & Total (Average) \\
\hline Military Intervention & 3 & 4 & 2 & $9(3)$ \\
Air strike & 2 & 3 & 1 & $6(2)$ \\
Diplomatic efforts & 4 & 2 & - & $6(2)$ \\
Do nothing & 1 & 1 & - & $2(0,6)$ \\
\hline
\end{tabular}

Ecevit administration argued that such a unification accompanied with sovereignty issues would make Turkey's western and southern borders insecure. The Turkish community's security was also significantly threatened by the coup. Therefore, the stakes were much too high to be ignored. In addition, the Turkish leadership in 1974 felt relatively more comfortable in the diplomatic and military dimensions. Therefore, a full-scale military intervention and diplomacy were ranked as the first two options. When the Ecevit government decided diplomacy would not bring the desired results, they engaged in perhaps the most important and controversial foreign policy decision in the history of the Turkish republic, whose effects are still in place after more than four decades. ${ }^{6}$

\section{Conclusion}

This study analyzed Turkey's decision-making processes by applying Mintz's (1993) PH decision-making model to the Cyprus crises of 1964, 1967, and 1974. It contributes to the decision-making, IR theory, and Turkish foreign policy literatures.

First, the study supports that the PH theory of decision-making is a useful framework for explaining leaders' decisions. The analysis, utilizing primary and secondary sources, suggests that Turkish leadership's actual decisions during the three crises parallel PH theory's expectations of a two-stage decision-making process. In each case, the three leaders eliminated the options that seemed too costly to engage in. Each crisis analysis also shows that after the elimination of noncompensatory options, Turkish leadership engaged in a "rational" calculation weighing different alternatives' pros and cons and pursued the course of action that they believed would bring the highest payoffs. The expected utility or lexicographic decision rules operated in the second stage. The most important key dimensions in all decisions were diplomatic/systemic and domestic politics. Using the noncompensatory model, the $\mathrm{PH}$ model reduces "the complexity of choice problem to a more structured and manageable decision problem" (Mintz 2002, 6). Table 5 summarizes all of the findings.

Second, the analysis also reveals interesting conclusions in terms of IR theory and middle power politics. The Cyprus military intervention of 1974 is an outlier decision for Turkish foreign policy; it remains the only unilateral major use of force by the Republic of Turkey in its century-long history that resulted in the occupation of territory. It is a very exceptional case in which a middle power takes large risks, uses force unilaterally, and antagonizes the major powers of the time. We argue that this rather bold decision of the Ecevit administration was made possible by two major factors: the easing of bipolar constraints on Turkey's choices and improvements in military capabilities.

The Turkish intervention in Cyprus is an example of a more chaotic world order in the absence of bipolar pressures. Waltz (1964) argues that bipolarity is stable not only because it balances power but also because it keeps smaller allies in

\footnotetext{
${ }^{6}$ It is important to note here that we analyze only Turkey's military intervention in July 1974. Turkey's second military operation in August 1974 was carried out with tactical military reasons in mind and is beyond this study's scope.
} 


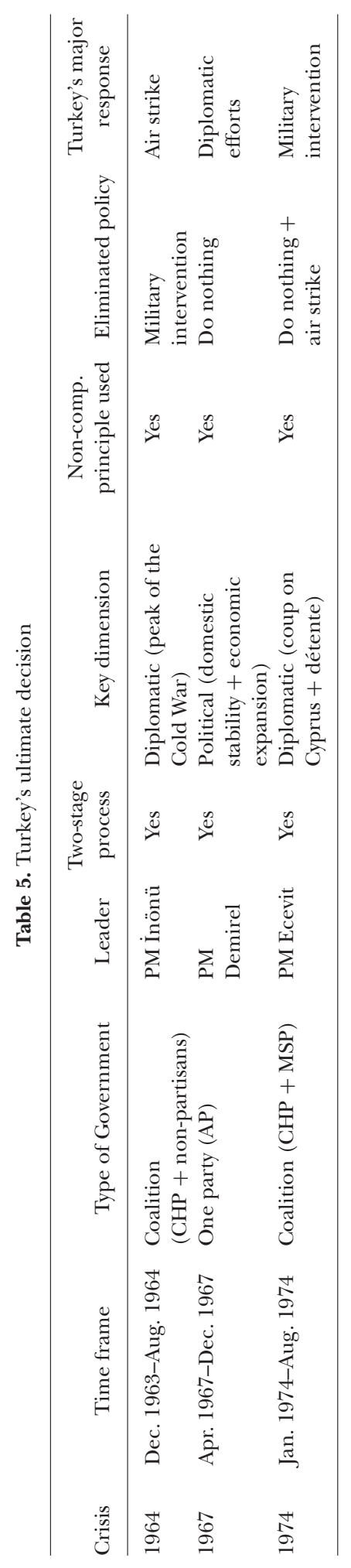


check. Often times, Cold War tensions kept middle or smaller powers in control because their superpower patrons prevented their adventurous behavior due to a fear of retaliation by the opposite pole. The US pressure on Turkey prevented war in 1964 and arguably affected the next administration's calculations in 1967 as well. After détente began in 1969, Turkey felt less US pressure as well as a lower level of Soviet threat.

This case also confirms realism's hypothesized relationship between military capabilities and foreign policy (Waltz 1979). In addition to the systemic and domestic political constraints, Turkey also did not have the military capabilities to intervene in 1964 and 1967, whereas it acquired a significant capability by the 1974 crisis. When systemic and domestic constraints were eased, Turkey could engage in the use of force with its newly equipped military. To sum up, Turkey's dealing with the three crises suggests that systemic opportunity coupled with military capabilities can lead to the "misbehavior" of middle powers in world politics, if leadership feels secure vis-à-vis their own political survival domestically.

Third, this study reveals interesting results with regard to Turkish foreign policy studies. Turkey's foreign policy was far from being autonomous during each Cyprus crisis. The United States acted as a constraining factor on Turkey's foreign policy in each case. US diplomacy aimed to control its ally's behavior in all three crises. In 1964 and 1967, the United States was able to bring Turkey to the line they favored, whereas in 1974, Turkey acted alone despite all efforts from Washington. Turkey has also been very concerned with subsystemic changes in the form of regional developments. In the minds of the foreign policy and military elite, Turkey has been losing territory and power against Greece-already a regional rival for a millennium-since the Greek revolution began in 1821. Enosis was considered to be the "last straw" in a one-and-a-half-century losing streak for Turkey. Strategic calculations about the regional balance of power were a significant factor in the decision to use force. We conclude systemic and subsystemic factors, as constraining influences on Turkey's behavior, were significant sources in the Turkish elite's decision-making. The $\mathrm{PH}$ analysis also suggests that the diplomatic dimension is a major factor in leaders' decisions.

Domestic politics have been as important as international factors in Turkish foreign policy decision-making. Each time one of the crises erupted, Turkey was busy with internal problems and not prepared for or expecting a crisis. In late 1963, when Cyprus witnessed intercommunity conflicts, Turkey had internal problems following the dissolution of the second Inönü coalition. Turkey could not formulate an official policy toward the crisis until after the formation of the third coalition under İnönü. In 1967, Demirel's administration was not prepared to confront an international crisis; it was busy with economic problems. In 1974, not aware of the coming crisis, the Ecevit administration was focused on revoking the ban on opium cultivation. Turkish policy-makers never saw any of the three crises coming. In each crisis, Turkey's foreign policy intelligence capabilities were modest at best.

Finally, these three decisions by Turkish officials confirm the central argument of the PH theory of use of force; that is, that "decisions to use force are based on two-step rejection or adoption of alternatives according to very limited criteria, particularly domestic political criteria" (Mintz 2002, 12). This article belongs to a larger argument that decisions to use force cannot be in conflict with the most important decision dimension as perceived by the leader (Mintz, Geva, and DeRouen 1994; Geva and Mintz 1997). Turkey's decisions in 1964, 1967, and 1974 clearly demonstrate that the Turkish leadership eliminated all those alternatives deemed "unacceptable" from the domestic political perspective. In the second stage, utility maximizing, cost minimizing strategic calculations followed. More specifically, the Turkish case shows that the domestic political dimension-political survival concerns - has been the most important one in the first stage, as suggested by the larger literature (Mintz 1993, 2002; DeRouen 2002; Geva and Mintz 1997; 
Astorino-Courtois and Tursty 2002; Sathasivam 2002). The three specific cases analyzed here in a comparative manner relate to the rest of the literature and confirm the importance of domestic politics in two-stage decision-making.

This article's conclusions also contribute to a larger, cross-discipline social science debate about decision-making. Rational choice studies have long argued that individuals make calculated, self-interested, utility-maximizing decisions. A refined understanding of rationality suggests that people make decisions based on the limitations of their information, cognitive capabilities, and time constraints in a given situation, such as during a crisis. The cognitive school suggests that many decisionmakers use "heuristics" in decision-making, which is far from the mechanical picture drawn by the earlier substantive rationality arguments. However, this does not mean that the cognitive school is "antirational." It argues that humans make decisions differently, based on "time constraints, prior beliefs, and experiences, limited searches for information, and a dominant goal or value that heavily influences the decision process" (DeRouen and Sprecher 2004, 57). In this sense, the rationalcognitive divide in political science has become a pseudo-debate that $\mathrm{PH}$ theory has attempted to remedy. The three Turkish cases analyzed here support the notion that humans make decisions based on-mostly-useful shortcuts, as well as analytical processes. Given the instability surrounding the Turkish governments during the 1960s and 1970s, the Turkish prime ministers' first response to the Cyprus crises was to avoid a large mistake that would upset the precarious domestic political balances. After eliminating the noncompensatory options based on their perceptions, beliefs, and time constraints related to domestic politics, they turned to weighing up different alternatives. In this sense, Turkey's decisions vis-à-vis the Cyprus crises supports the notion that rational, effortful, slow decision-making is preceded by an automatic, fast, and sometimes unconscious process. We believe further comparative research on Turkey's decisions on both Iraq wars (i.e., 1990-91 and 2003) can both enhance our understanding of contemporary Turkish decision-making on foreign policy and contribute to the PH model.

\section{References}

A.P. (Adalet Partisi). 1965. Seçim Beyannamesi (Election Manifesto). Ankara: Doğuş Matbaacılık. . 1972. Millet Hizmetinde Adalet Partisi 1965-1971 (Serving the Nation 1965-1971). Ankara: Ayyldız Matbaası.

Adams, T. W. 1966. "The First Republic of Cyprus: A Review of an Unworkable Constitution.” The Western Political Quarterly 19 (3): 475-90.

ArCayürek, Cüneyt. 1985. Demirel dönemi, 12 Mart darbesi: 1965-1971 (The Demirel Era, Coup of 12 March: 1965-1971). Ankara: Bilgi Yayınevi.

—. 2006. Bir Özgürlük Tutkunu Bülent Ecevit (Bülent Ecevit: A Passion for Freedom). Istanbul: Detay Yayıncılık.

Asmussen, Jan. 2008. Cyprus At War: Diplomacy and Conflict during the 1974 Crisis. London: I.B. Tauris \& Co Ltd.

Astorino-Courtois, Allison, and Brittani Trusty. 2002. "Degrees of Difficulty: The Effect of Israeli Policy Shifts on Syrian Peace Decisions." In Integrating Cognitive and Rational Theories of Foreign Policy Decision Making, edited by Alex Mintz, 29-54. New York, NY: Palgrave Macmillan.

Aziz, Aysel. İ. 1969. "1964 Yılında Kıbrıs Buhranı Ve Sovyetler Birliği” (1964 Cyprus Crisis and the Soviets). Siyasal Bilgiler Fakültesi Dergisi 24 (3): 167-210.

Bahcheli, Tozun. 2014. "Cyprus 1974: Turkey's Military Success Followed by Political Stalemate.” Mediterranean Quarterly 25 (1): 6-21.

Below, Аmy. 2008. "U.S. Presidential Decisions on Ozone Depletion and Climate Change: A Foreign Policy Analysis." Foreign Policy Analysis 4 (1): 1-20.

Birand, Mehmet. A. 1987. 30 Sicak Gün (Thirty Hot Days). Istanbul: Milliyet Yayınları.

BölüKBaşı, SüHA. 1993. “The Johnson Letter Revisited.” Middle Eastern Studies 29 (3): 505-25.

—. 2001. Barışıı Cözümsüzlük (Peaceful Non-Settlement). Ankara: Iṁe Kitabevi.

Brecher, Michael, And J. Wilkenfeld. 2000. A Study of Crisis. Ann Arbor: University of Michigan Press. 
Brecher, Michael, and Jonathan Wilkenfeld, Kyle Beardsley, Patrick James, and David Quinn. 2017. "International Crisis Behavior Data Codebook, Version 12." http://sites.duke.edu/icbdata/datacollections/.

BRule, DAvid J. 2005. "Explaining and Forecasting Leaders' Decisions: A Poliheuristic Analysis of the Iran Hostage Rescue Decision.” International Studies Perspectives 6 (1): 99-113.

Bueno de Mesquita, Bruce, Smith, Siverson, and James D. Morrow. 2003. The Logic of Political Survival. Cambridge, MA: MIT Press.

Constandinos, Andreas. 2009. America, Britain and the Cyprus Crisis of 1974: Calculated Conspiracy or Foreign Policy Failure? Central Milton Keynes, UK: Author House.

Constandinos, Andreas. 2011. "US-British Policy on Cyprus, 1964-1974." The Cyprus Review 23 (1): 1748.

Coufoudakis, VAn. 2003. "The Cyprus Question: International Politics and the Failure of Peacemaking." In Greece in the Twentieth Century, edited by T. A. Couloumbis, T. Kariotis and F. Bellou, 111-35. London: Frank K. Cass.

C.S.T.D. (Cumhuriyet Senatosu Tutanak Dergisi). 1964. Yirmiüçüncü Birleşim, January 3, 1964.

Çuhadar-Gürkaynak, Esra, and B. ÖZkeçeci-Taner, 2004. "Decision Making Process Matters: Lessons Learned from Two Turkish Foreign Policy Cases.” Turkish Studies 5 (2): 43-78.

Dacey, Raymond, and L. J. Carlson. 2004. "Traditional Decision Analysis and the Poliheuristic Theory of Foreign Policy Decision Making.” Journal of Conflict Resolution 48 (1): 38-55.

Danopoulos, Constantine. 1982. "The Greek Military Regime (1967-1974) and the Cyprus QuestionOrigins and Goals.” Journal of Political and Military Sociology 10 (2): 257-73.

DeRouen, Karl. 2002. "The Decision Not to Use Force at Dien Bien Phu: A Poliheuristic Perspective." In Integrating Cognitive and Rational Theories of Foreign Policy Decision Making, edited by Mintz Alex, 11-28. New York: Palgrave Macmillan.

DeRouen, Karl, And C. Sprecher. 2004. "Initial Crisis Reaction and Poliheuristic Theory." Journal of Conflict Resolution 48 (1): 56-68.

Dodd, H. Clements. 2010. The History and Politics of the Cyprus Conflict. New York: Palgrave Macmillan.

Ecevit, BüLent. 2010. Ecevit'in Açıklamalar 1976 (Statements of Ecevit: 1976). İstanbul: Türkiye İş Bankası Kültür Yayınları.

ERhan, ÇAĞRI. 1996. Beyaz Savass: Türk-Amerikan Iliskilerinde Afyon Sorunu (The White War: The Opium Question in Turkish-American Relations). Ankara: Bilgi Yayinevi.

ЕRiм, NıнAт. 1975. Bildiğim ve gördüğ̈̈m ölçüler içinde Kıbrıs (Cyprus as I Know and Witness). Ankara: AjansTü̈k Matbaacılık Sanayii.

Ertekün, N. Münur. 1984. The Cyprus Dispute and the Birth of the Turkish Republic of Northern Cyprus, 2nd ed. Nicosia, Northern Cyprus: K. Rustem.

Evcil, CumHur. 1999. Yavru Vatan Kıbris'ta Zaferin Hikaŷesi (The Story of Victory in Cyprus). Ankara: Genelkurmay Basım Evi.

F.R.U.S. (The Foreign Relations of the United States). 2000. Greece; Cyprus; Turkey, 1964-1968. Edited by J. E. Miller. Washington: United States Government Printing Office.

—. 2007. Greece; Cyprus; Turkey, 1973-1976. Edited by L. V. Hook. Washington: United States Government Printing Office.

Geva, Nehemia, and Alex Mintz, ed. 1997. Decisionmaking on War and Peace: The Cognitive-rational Debate. Boulder, CO: Lynne Rienner Publishers, Inc.

Göktepe, Сiнat. 2005. "The Cyprus Crisis of 1967 and Its Effects on Turkey's Foreign Relations.” Middle Eastern Studies 41 (3): 431-44.

Gürün, Kamuran. 1983. Dış Iliş̧kiler ve Türk Politikası (Turkish Foreign Policy). Ankara: Ankara Universitesi SBF Yayınları.

Hale, M. William. 2000. Turkish Foreign Policy, 1774-2000. London: Frank Cass.

HART, T PARKer. 1990. Two NATO Allies at the Threshold of War: Cyprus, a Firsthand Account of Crisis Management, 1965-1968. Durham, NC: Duke University Press.

Heper, Metin. 1998. The Making of a Turkish Statesman. Leiden: Brill.

Hitchens, Christopher. 1997. Hostage to History: Cyprus from the Ottomans to Kissinger. 3rd ed. Brooklyn, NY: Verso Books.

Hughes-Wilson, John. 2011. "The Forgotten War.” The RUSI Journal 156 (5): 84-93.

İNÖnÜ, İsmET. 1961. "Müzakere ve Milli Menfaat" (Negotiation and National Interest). In CHP: Dış Politika, CHP. Ankara: Rüzgarlı Matbaa.

James, Patrick, And E. Zhang. 2005. "Chinese Choices: A Poliheuristic Analysis of Foreign Policy Crises, 1950-1996.” Foreign Policy Analysis 1 (1): 31-54.

Kaufmann, Chaim. 2007. "An Assessment of the Partition of Cyprus." International Studies Perspectives 8 (1): 206-23. 
Ker-Lindsay, James. 2004. Britain and the Cyprus Crisis, 1963-1964. Mannheim, Germany: Bibliopolis.

—. 2011. The Cyprus Problem: What Everyone Needs to Know. Oxford: Oxford University Press.

KeSER, Ulvi. 2007. Kıbris'ta yeraltı faaliyetleri ve Türk Mukavemet Teskilâtı: 1950-1963 (Underground Organizations in Cyprus and the Turkish Resistance Organization). Istanbul: IQ Kültür Sanat Yayıncılık.

Kissinger, Henry. 1982. Years of Upheaval. London: Weidenfeld \& Nicholson.

KışLALı, M. Ati. 1964. "Batı İttifakı Yıkılır” (Western Alliance Can Dissolve). Milliyet, April 16, 1964.

KomşuoĞLu, Arşe. 2008. Türkiye Siyasetinde Bir Lider: Süleyman Demirel (Süleyman Demirel: A Leader in Turkish Politics). Istanbul: Bengi Yayınları.

Levi, Avner. 1991. "The Justice Party, 1961-1980.” In Political Parties and Democracy in Turkey, edited by Metin Heper and J. M. Landau. London: I.B. Tauris.

Mallinson, William. 2005. Cyprus: A Modern History. London: I.B. Tauris \& Co Ltd.

Miller, James Edward. 2009. The United States and the Making of Modern Greece: History and Power, 1950-1974. Chapel Hill: The University of North Carolina Press.

Milliyet. 1964. "Hükümet 'Güven Oyu' Aldı" (The Government won the confidence vote). Milliyet, June 20, 1964.

— 1974. "Koalisyonun Yürümesi İçin Çaba Harcanacak" (Efforts to Save the Coalition). Milliyet, May $21,1974$.

Mintz, Alex. 1993. "The Decision to Attack Iraq: A Noncompensatory Theory of Decision Making." Journal of Conflict Resolution 34 (4): 595-613.

— 2002. "Integrating Cognitive and Rational Theories of Foreign Policy Decision Making: A Poliheuristic Perspective." In Integrating Cognitive and Rational Theories of Foreign Policy Decision Making, edited by Alex Mintz, 1-9. New York: Palgrave Macmillan.

— 2004. "How Do Leaders Make Decisions? A Polyheuristic Perspective." Journal of Conflict Resolution 48 (1): 3-13.

— 2005. "Applied Decision Analysis: Utilizing Poliheuristic Theory to Explain and Predict Foreign Policy and National Security Decisions." International Studies Perspectives 6 (1): 94-98.

Mintz, Alex, Nehemia Geva, and Karl Derouren. 1994. "Mathematical Models of Foreign Policy DecisionMaking: Compensatory vs. Noncompensatory.” Synthese 100 (3): 441-60.

Mintz, Alex, and R. Karl DeRouen. 2010. Understanding Foreign Policy Decision Making. Cambridge: Cambridge University Press.

M.M.T.D. (Millet Meclisi Tutanak Dergisi). 1964. Ellibeşinci Birleşim. February 18, 1964.

- 1965. Yirmisekizinci Birleșim. December 27, 1965.

—. 1974. Зüncü Birleşim 1inci ve 4üncü Oturum. July 20, 1974.

O’Malley, Brendan, and In Craig. 2001. The Cyprus Conspiracy: America, Espionage and the Turkish Invasion. London: I.B. Tauris \& Co Ltd.

Oran, Baskin. 2001. Türk Dış Politikası (Turkish Foreign Policy). Istanbul: Iletișim.

Purcell, H. D. 1969. Cyprus. New York: Frederick A Praeger.

Redd, B. Steven, And A. Mintz. 2013. "Policy Perspectives on National Security and Foreign Policy Decision Making.” The Policy Studies Journal 41 (1): 11-37.

Rizas, Sotiris. 2009. "Managing a Conflict between Allies: United States Policy towards Greece and Turkey in Relation to the Aegean Dispute, 1974-76." Cold War History 9 (3): 367-87.

SAlem, Norma. 1992. "The Constitution of 1960 and Its Failure." In Cyprus: A Regional Conflict and Its Resolution, edited by Norma Salem, 117-25. London: Palgrave Macmillan.

Sambanis, Nicholas. 1999. "The United Nations Operation in Cyprus: A New Look at the PeacekeepingPeacemaking Relationship.” International Peacekeeping 6 (1): 79-108.

Sandal, A. Nukhet, Z. Enyu, C. C. James, and P. James. 2011. "Poliheuristic Theory and Crisis Decision Making: A Comparative Analysis of Turkey with China." Canadian Journal of Political Science / Revue canadienne de science politique 44 (1): 27-57.

Sathasivam, Kanishkan. 2002. “'No Other Choice': Pakistan's Decision to Test the Bomb.” In Integrating Cognitive and Rational Theories of Foreign Policy Decision Making, edited by Alex Mintz, 55-76. New York: Palgrave Macmillan.

Simon, Herbert. A. 1957. Models of Man: Social and Rational. New York: John Wiley and Sons, Inc.

Sirin, V. Cigdem. 2012. "Examining the Role of Identity in Negotiation Decision Making: The Case of Cyprus." International Journal of Conflict Management 23 (4): 413-39.

SönmezoĞLu, Faruk. 1991. Taraflarn tutum ve tezleri açısından Kıbrıs sorunu: 1945-1986 (Cyprus Question and Parties' Stands and Views). Istanbul: I:U: Basımevi ve Film Merkezi.

—. 1995. ABD'nin Türkiye Politikası (1964-1980) (US Policy toward Turkey). İstanbul: Der Yayınevi. 2000. Tǚkiye-Yunanistan ilişkileri ve buÿü̈ gü̈ler (Turkey-Greece Relations and Great Powers). Istanbul: Der Yayınları.

ŞAHIN, HaLuk. 2002. Johnson Mektubu (Johnson Letter). Istanbul: Gendas, 
Toker, Metin. 1992. Inönü’nün Son Başbakanlı̆g: 1961-1965 (Last Premiership of İnönü). Ankara: Bilgi Yayınevi.

Uslu, Nasum. 2003. The Cyprus Question as an Issue of Turkish Foreign Policy and Turkish-American Relations, 1959-2003. New York: Nova Science Publishers.

Waltz, N. Kenneth. 1964. "The Stability of a Bipolar World." Daedalus 93 (3): 881-909.

— 1979. Theory of International Politics. Reading, MA: Addison-Wesley.

YavuZalp, Ercüment. 1996. Liderlerimiz ve diş politika (Our Leaders and Foreign Policy). Ankara: Bilgi.

Ye, Min. 2007. "Poliheuristic Theory, Bargaining, and Crisis Decision Making." Foreign Policy Analysis 3 (4): 317-44. 